\title{
A Neoproterozoic age for the chromitite and gabbro of the Tapo ultramafic Massif, Eastern Cordillera, Central Peru and its tectonic implications
}

\author{
Colombo C.G. Tassinari , Ricardo Castroviejo -, Jose F. Rodrigues , Jorge Acosta , Eurico Pereira \\ a Instituto de Geociências da Universidade de São Paulo, Rua do Lago 562, Cidade Universitaria, São Paulo, CEP 05508-080, Brazil \\ ${ }^{\mathrm{b}}$ Universidad Politecnica de Madrid, E.T.S. Ing. Minas, c/Ríos Rosas 21, 28003 Madrid, Spain \\ ${ }^{\mathrm{c}}$ Laboratorio Nacional de Energia e Geologia, Rua da Amieira, Apartado 1089, 4466-901 São Mamede de Infesta, Portugal \\ ${ }^{\mathrm{d}}$ Instituto Geológico Minero y Metalúrgico, Dirección de Recursos Minerales y Energéticos, Av. Canadá 1470, Lima 41, Peru
}

\begin{abstract}
A B S T R A C T
The ultramafic-mafic rocks of the Tapo Complex are exposed in the Eastern Cordillera of the Central Peruvian Andes. This complex is composed of serpentinised peridotites and metabasites with some podiform chromitite lenses and chromite disseminations and overlies the sandstones, conglomerates, and tuffs of the Carboniferous Ambo Group. The metagabbros and amphibolites show a tholeiitic affiliation and a flat REE spider diagram, with a slight LREE depletion and a positive Eu anomaly suggesting magmatic accumulation of plagioclase, in an ocean ridge or ocean island environment. Sm-Nd isotopic analyses were performed on chromite as well as on whole rock from the gabbro. All samples yielded an $\mathrm{Sm}-\mathrm{Nd}$ isochrone age of $718 \pm 47 \mathrm{Ma}$ with an initial ${ }^{143} \mathrm{Nd} /{ }^{144} \mathrm{Nd}$ of $0.51213 \pm 0.00005$. The $\varepsilon_{\mathrm{Nd}}(718 \mathrm{Ma})$ values calculated for both chromite and gabbro are in close agreement, around 8.0, implying that they were formed at the same time from the same mantelic magma source. Furthermore a $\mathrm{K}-\mathrm{Ar}$ age on amphibole of $448 \pm 26 \mathrm{Ma}$ was obtained, interpreted as the cooling age of a younger orogenic event. These rocks represent slices of oceanic crust (from a dismembered ophiolitic complex), metamorphosed and later overthrust on upper Palaeozoic continental formations.
\end{abstract}

\section{Introduction}

A highly dismembered assemblage of ultramafic and mafic rocks is exposed in the Eastern Cordillera of the Central Peruvian Andes, extending along a discontinuous NW-SE belt over some $250 \mathrm{~km}$ between $12^{\circ}$ and $9^{\circ} \mathrm{S}$ of latitude (between Huancapallac and Tapo, s. inset in Fig. 1). One of the most important occurrences is the Tapo Mafic-Ultramafic Complex, which occurs at 3750-4200 $\mathrm{m}$ above sea level, $2 \mathrm{~km}$ west of the village of Tapo, in the Tarma province, about $200 \mathrm{~km}$ west of Lima.

The Tapo Complex is a lens-shaped body, $5 \mathrm{~km}$ long and $1-2 \mathrm{~km}$ wide, that consists mainly of strongly serpentinised peridotites and some gabbros. Several small open pits won chromite from podiform chromitite lenses ( $\geq 60 \%$ chromite) and from disseminated chromite in serpentinite, but mining is no longer active.

The main structure trends of the Tapo Complex is NW-SE and the massif is tectonically emplaced upon Lower Carboniferous sedimentary rocks. There were no radiometric ages available for the ultramafic and mafic rocks, but Castroviejo et al. (2009b), proposed a Pre-Andean age for the emplacement of the massif. The rocks of the Tapo Massif are overprinted by metamorphism reaching the lower amphibolites facies, but no metamorphism is observed in the sediments of the footwall.

One of the most difficult tasks in geochronology is to date serpentinised ultramafic-mafic rocks. This is due to the fact that most geochronological techniques are not adequate to date ultramafic rocks and, in addition, there is the opening of the radiometric systems during the superimposed serpentinisation episodes. This work intends to constrain the protolith age of the Tapo Complex, using Sm-Nd technique direct dating of chromites and whole-rock sample from the host gabbro. In addition $\mathrm{K}-\mathrm{Ar}$ age determination on amphibole from the gabbro is presented to estimate the time of the metamorphic overprint. These data are very important to improve the constraints about the tectonic events and the reconstruction of the Gondwana margin of the Peruvian Andes.

\section{Geological setting}

The Pre-Andean basement is extensively exposed in the Cordillera Oriental (Fig. 2). Some first order stratigraphic and metamorphic discontinuities are briefly outlined following 


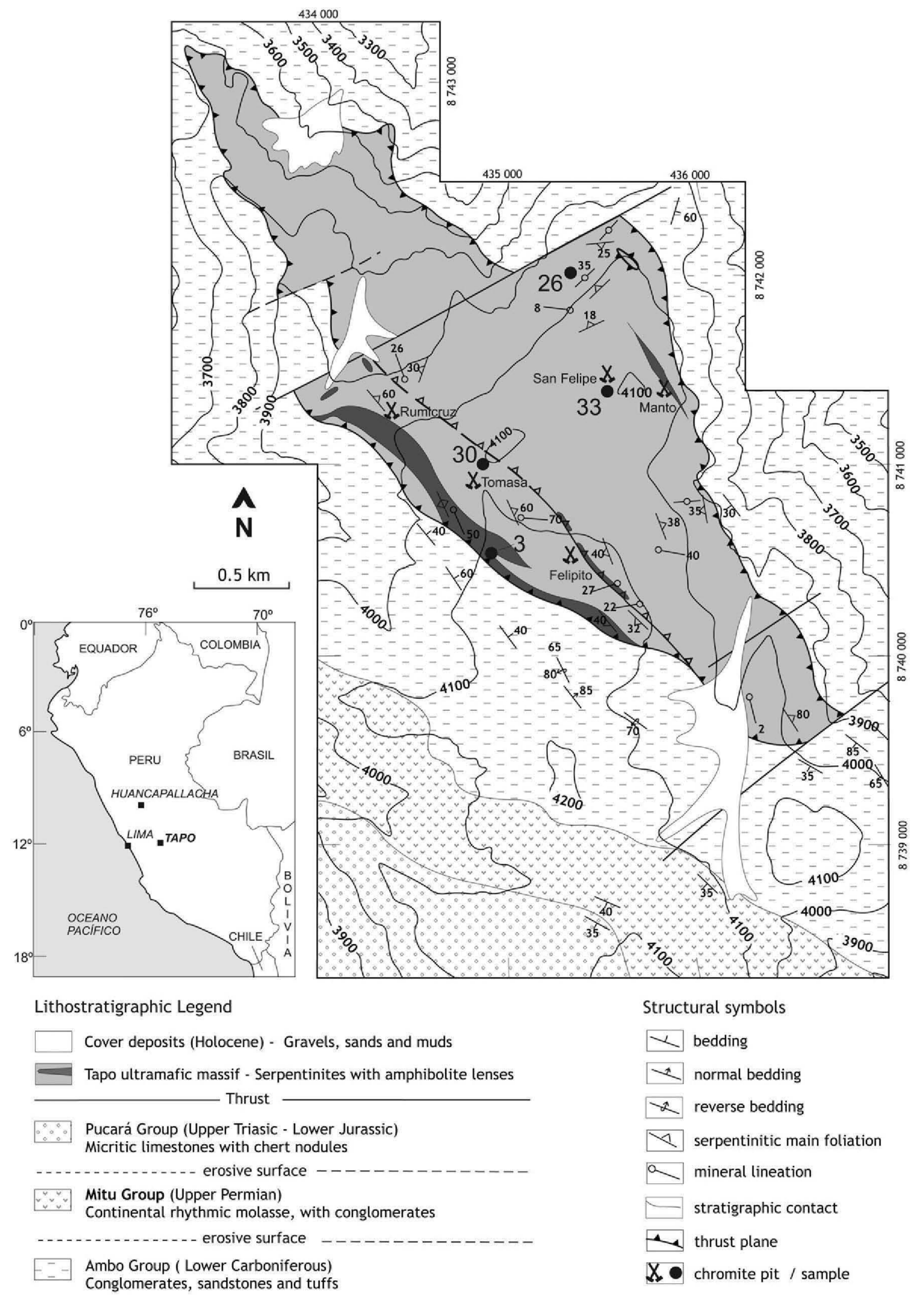

Fig. 1. Geological map of the Tapo ultramafic Massif, showing location of dated samples ( $\mathrm{n}^{\circ} 30=$ TP140607-030; 33 = TP150607-033; 26 = 260607-C; and 3 $=090606-003$, Tables 3 and 4). 


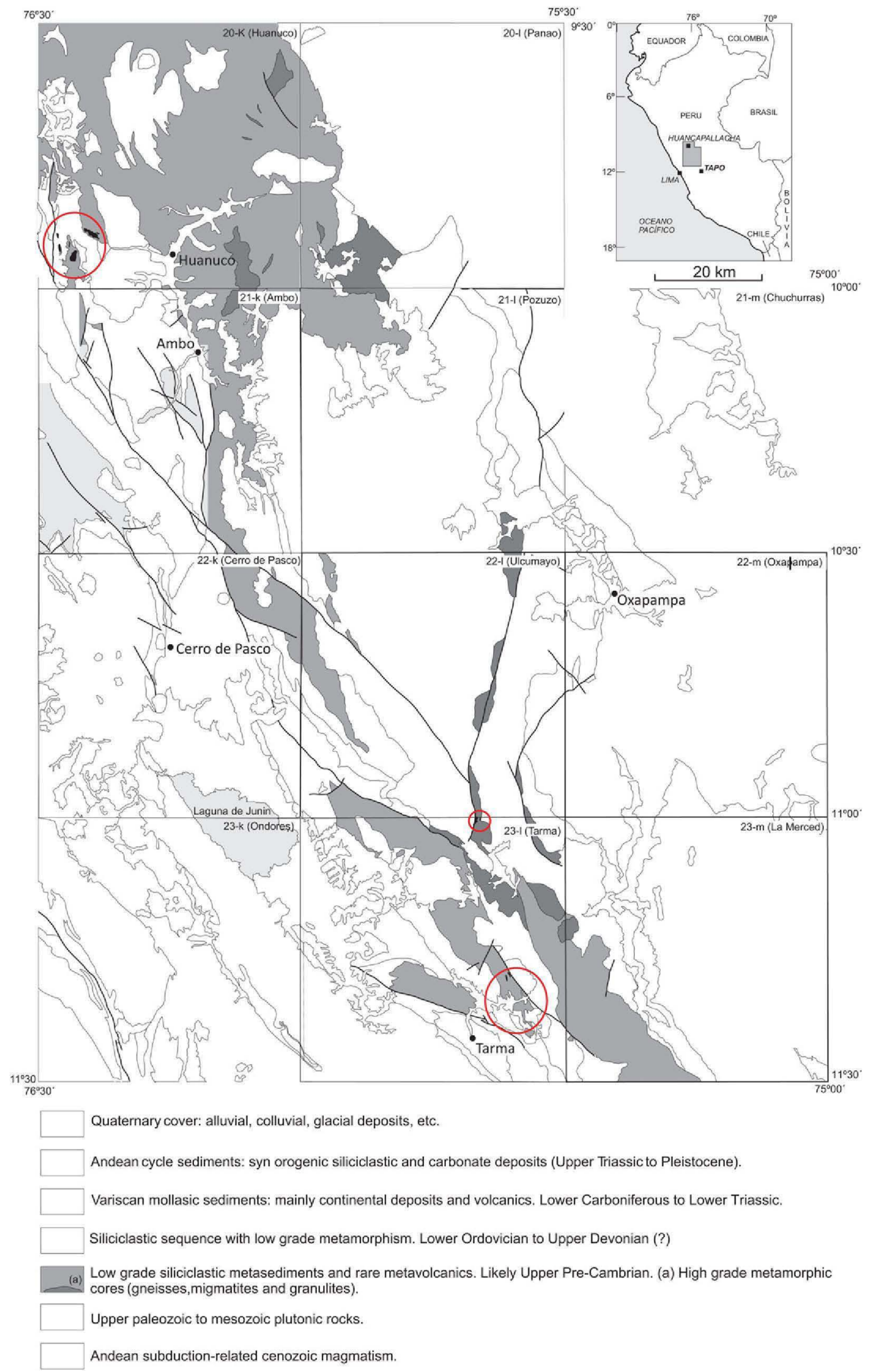

Fig. 2. Geological sketch of the Eastern Cordillera $\left(9^{\circ} 30^{\prime}-11^{\circ} 30^{\prime}\right)$, with location of known ultramafic-mafic occurrences (marked with circles). 
Dalmayrac et al. (1980), whose scheme is adapted to the Tarma region. The oldest unit is a low grade metasedimentary sequence of terrigenous origin with some metavolcanic intercalations (Huácar Group), for which a Precambrian age was first proposed (Megard et al., 1996), but recent geochronological data show that orogenic events in the Peruvian Eastern Cordillera occurred during Lower Palaeozoic times (Chew et al., 2007). This unit is overlain unconformably by a Lower Palaeozoic marine sequence which is covered by Late Palaeozoic to Lower Triassic, tardi- or post-tectonic sediments of marine and continental facies, including the Ambo and the Mitu Groups. The sedimentary sequences of the Andean cycle rest upon an erosional surface over the former units (from Precambrian to Upper Palaeozoic). In the studied region the Andean cycle begins with an Upper Triassic - Lower Jurassic carbonate sequence (Pucará Group). Intrusive rocks of various ages and recent deposits complete the regional framework.

In the Tarma area, three ultramafic occurrences are known: Tapo, named after the near village E of Tarma, and two smaller bodies occurring $\sim 7 \mathrm{~km}$ NE of Acobamba (Megard et al., 1996; Castroviejo et al., 2009a). Only the main one, the Tapo massif, has been sampled for isotopic analysis. The extreme serpentinisation, and the absence of chromite or other primary magmatic minerals in the Acobamba bodies preclude dating their magmatic crystallization. Nevertheless Castroviejo et al. (2009a) shows that their geology, structure, emplacement, and therefore their age, are similar to those of the main body, Tapo.

The main body of ultramafic rocks, the Tapo Massif (Fig. 1) comprises serpentinites with minor lenses of amphibolites which lie over the Lower Carboniferous sandstones, conglomerates, and tuffs of the Ambo Group; these sediments show no signs of thermal metamorphism. The contact shows clear evidences of cataclasis, both in the serpentinites of the hangingwall, and in the Ambo deposits of the footwall (Fig. 3). This basal contact as well as the overlying serpentinites, are folded together with the Ambo sediments by an NW-SE Andean folding phase. The internal deformation of the ultramafites shows a strongly non-coaxial character that is interpreted as the result of a Pre-Andean tectonic event. Yet the main foliation transposes another one, observable in microlithons that should correspond to an older episode of mantelic deformation (Rodrigues et al., 2010a,b).

To summarize the geological setting, the implications of the essential features of the Tarma ultramafites, Tapo and Acobamba

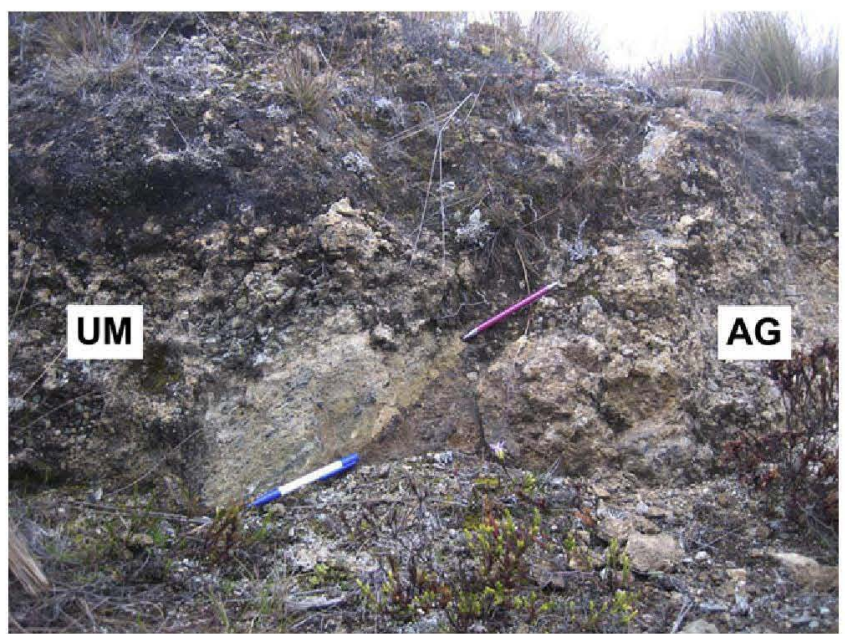

Fig. 3. Tectonic contact between the serpentinised Tapo ultramafites (top, labelled UM) and the siliciclastic sediments of the Ambo Group (below, AG). The contact follows exactly the line marked by the two pencils, evidencing a brittle behaviour with intensive cataclasis of both lithologies near the contact.
(Castroviejo et al., 2009b), are briefly reminded. The tectonic nature of the contacts (always thrusts or faults), the existence of a strong shear deformation associated to the ultramafites, but not observed in the siliciclastic sequences of the basement (either Huácar or Ambo Groups), together with the absence of any evidence of thermal metamorphism in the latter, show clearly the allochtonous emplacement of the ultramafic bodies in their present position, and preclude the previously accepted hypothesis (Megard et al., 1996, and references therein) of ultrabasic magma intrusion in these sequences. Relict internal features in the ultramafites witness a previous deformational history not found in the footwall rocks (Rodrigues et al., 2010a,b). Moreover, the chromite ores are of the podiform type, and do not correspond to the stratified concentrations typical of intrusions (Castroviejo et al., 2010b) and finally, as shown below, metabasite geochemistry suggests an ocean ridge or an ocean island protolith.

\section{Petrology}

The petrographic and geochemical characterisation of the ultramafic/mafic lithologies is briefly discussed. Most of the ultramafites are totally altered to serpentinites and extremely deformed. Sheared serpentinites and serpentine mylonites are the most common lithology. Extreme metasomatism of the ultramafites produces locally silica and carbonate-silica hydrothermalites, birbirites and listvaenites, due to hydrothermal fluid circulation enhanced along thrusts and faults.

Peridotitic remnants are scarce and, when found, are usually overprinted by serpentinisation. Olivine or pyroxene relics, suggesting dunitic and harzburgitic or lherzolitic protoliths, are rarely seen; these minerals are usually represented by serpentinised pseudomorphs or ghosts (Fig. 4).

Chromite is the main primary mineral left in the ultramafic rocks; it is also (together with subordinate magnetite or other members of the spinel familly) the only one that may be locally abundant. Chromite ores occur as small podiform chromitite lenses and disseminated in chromite serpentinites throughout the massif. Both types show a relatively simple primary mineralogy (chromite, magnetite, traces of pyrite, chalcopyrite, pyrrhotite, and millerite? as minute inclusions). Modification of the ores by metamorphism

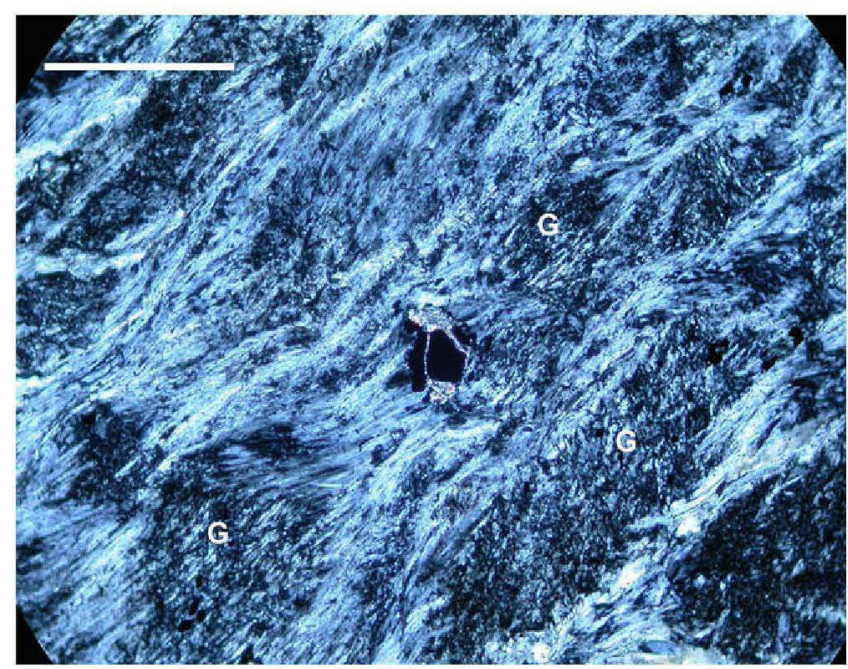

Fig. 4. Serpentine schist preserving microclast ghosts (G) after pre-tectonic olivine and pyroxene from peridotite tectonite. The schistose bands are composed mostly of antigorite, with sparse, minute chromite and magnetite relics, black; other components, not seen in the picture, are talc and kämmererite (Sample 110806.23, transmitted light photomicrograph, XP, scale bar: $0.25 \mathrm{~mm}$ ). 
Table 1

Whole-rock XRF analyses of major element contents from the Tapo Massif metabasites (metagabbro, amphibolites) (Analyses by Laboratorio Nacional de Energia e Geologia, Porto, Portugal).

\begin{tabular}{lllllll}
\hline \multicolumn{7}{l}{ Samples/\% oxides } \\
\cline { 2 - 7 } & $090606-02$ & $090606-03$ & $260607-01$ & $090607-02$ & $090607-3$ & $130607-12$ \\
\hline $\mathrm{SiO}_{2}$ & 40.01 & 49.43 & 47.25 & 42.53 & 42.94 & 50.7 \\
$\mathrm{Al}_{2} \mathrm{O}_{3}$ & 10.11 & 11.55 & 15.87 & 13.05 & 10.85 & 15.18 \\
$\mathrm{Fe}_{2} \mathrm{O}_{3 \mathrm{~T}}$ & 21.86 & 14.13 & 9.2 & 19.11 & 23.1 & 8.79 \\
$\mathrm{MnO}$ & 0.18 & 0.15 & 0.15 & 0.19 & 0.26 & 0.16 \\
$\mathrm{CaO}$ & 8.11 & 10.84 & 11.13 & 11.49 & 9.42 & 7.84 \\
$\mathrm{MgO}$ & 7.98 & 6.8 & 7.95 & 7.26 & 6.54 & 8.67 \\
$\mathrm{Na}_{2} \mathrm{O}$ & 0.22 & 3.06 & 2.47 & 1.09 & 1.69 & 4.84 \\
$\mathrm{~K}_{2} \mathrm{O}$ & 0.06 & 0.12 & 0,04 & 0.23 & 0.08 & 0.17 \\
$\mathrm{TiO}_{2}$ & 3.26 & 2.57 & 0.93 & 2.35 & 3.4 & 0.41 \\
$\mathrm{P}_{2} \mathrm{O}_{5}$ & $<0.03$ & 0.13 & 0.08 & $<0.03$ & $<0.03$ & $<0.03$ \\
$\mathrm{LOI}$ & 8.03 & 1.03 & 4.88 & 2.56 & 1.57 & 2.96 \\
$\mathrm{TOTAL}^{9}$ & 99.85 & 99.71 & 99.95 & 99.89 & 99.88 & 99.75 \\
\hline
\end{tabular}

or by metasomatism related to deformation is commonly scarce, allowing a sound age determination as shown below. However, minor changes may locally occur, e.g. in San Felipe mine (Fig. 1): mobilization of $\mathrm{Cr}$ and its subsequent precipitation as breccia cement in the form of the carbonate stichtite, or as the Cr-bearing chlorite, kämmererite; replacement of chromite by pyrophanite or Mn-ilmenite, etc. (Castroviejo et al., 2009c, 2010c). Chromite crystals are frequently zoned, with an inner core of chromite and outer rims enriched in $\mathrm{Fe} /$ depleted in $\mathrm{Al}$; a detailed microprobe study shows subtle compositional variation trends between $\mathrm{Al}-$ and $\mathrm{Cr}-$ rich chromites, ferritchromite and magnetite, differing slightly in disseminated and massive ores (Fanlo et al., 2009).

The metabasites as well are rarely fresh, but careful mapping made it possible to find some useful samples for petrography, also offering some reliable information for geochemistry (Tables 1-3). The most common field types are banded metagabbros or hornblende-plagioclase \pm garnet amphibolites with flaser or nematoblastic fabric, often brecciated and sometimes mylonitic. They represent basaltic to picrobasaltic protoliths, and show a tholeiitic affiliation (Figs. 5 and 6) and a flat REE spider diagram, with a slight LREE depletion and a positive Eu anomaly suggesting magmatic accumulation of plagioclase, in an ocean ridge or ocean island environment (Figs. 7 and 8). Strong hydration and leaching of most trace elements, enhanced by dynamic metamorphism, prevents further definition of the protoliths. Resulting petrographic types are varied (chlorite or chlorite-serpentine schists, mylonites or blastomylonites, amphibole-chlorite-serpentine-titanite schists and breccias, garnet-epidote granofelses, etc.), and include rodingites or gabbro-derived metasomatic rocks with a peculiar calc-silicate mineralogy (grossular, zoisite, epidote, wollastonite, titanite, tremolite) as well as chlorite \pm albite, ilmenite and relic pyroxene/ plagioclase. Field relations are obscured by extreme deformation, and tectonic transposition of the contacts masks the original geometry.

\section{Samples and analytical procedures}

Samples of chromite and host gabbro were chosen both for $\mathrm{Sm}-\mathrm{Nd}$ isotopic analysis on isolated minerals (chromite, hornblende, plagioclase) and whole rock (metagabbro) and for $\mathrm{K}-\mathrm{Ar}$ analysis on gabbro amphibole. Widespread serpentinisation and retrometamorphism related to deformation made the selection of fresh samples for analysis a difficult task. Those that were finally analysed, after careful field and petrographic examination, are the best specimens available, either for the presence of primary magmatic minerals (chromite) or of the regional metamorphic assemblage.

The sample 090606-003 corresponds to a brecciated metagabbro, occurring as part of the main metabasite body: an NW-SE trending band, near the SW margin of the Tapo massif. The rock comprises as main minerals amphibole, plagioclase and epidote, with subordinate titanite, chlorite and quartz. It is strongly deformed and overprinted by a brittle stage, but earlier metamorphic orientation and banding can still be recognized.

The sample 260607-C corresponds to a chromite-rich serpentinite, to the north of the main chromite mine (San Felipe). The rock is strongly deformed, but most of the chromite is preserved as disseminated microclasts or porphyroclasts, commonly of $0.1-2.5 \mathrm{~mm}$ size, which build up over $25 \%$ of the rock. A small portion of the chromite has been comminuted to less than $0.01 \mathrm{~mm}$ sized particles which show up in fine bands parallel to the schistosity. The rock can be classified as a chromite-rich chloriteserpentine schist. Its main components are serpentine, chlorite, and chromite/magnesioferrite (as determined by XR diffraction). Disseminated magnetite and scarce sulphides (pyrite, siegenite?)

Table 2

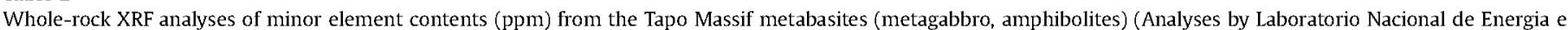
Geologia, Porto, Portugal).

\begin{tabular}{|c|c|c|c|c|c|c|c|c|c|c|c|c|c|c|c|c|c|c|c|c|c|c|c|c|c|}
\hline Samples & $\mathrm{Rb}$ & $\mathrm{Sr}$ & $\mathrm{Y}$ & $\mathrm{Zr}$ & $\mathrm{Nb}$ & $\mathrm{Ba}$ & $\mathrm{Ta}$ & $\mathrm{Sn}$ & W & Th & $\mathrm{Hf}$ & $\mathrm{U}$ & $\mathrm{La}$ & $\mathrm{Ce}$ & $\mathrm{Nd}$ & $\mathrm{Sm}$ & $\mathrm{Yb}$ & $\mathrm{Ni}$ & $\mathrm{Cu}$ & $\mathrm{Zn}$ & $\mathrm{Pb}$ & V & $\mathrm{Cr}$ & $\mathrm{Co}$ & $\mathrm{Ga}$ \\
\hline $090606-02$ & 4 & 35 & 18 & 14 & $<3$ & 36 & $<5$ & $<6$ & $<6$ & $<5$ & $<7$ & $<4$ & $<5$ & $<5$ & $<6$ & $<6$ & $<6$ & 150 & 237 & 105 & $<6$ & 1580 & 11 & 86 & 18 \\
\hline $090606-03$ & $<3$ & 232 & 36 & 44 & $<3$ & 66 & $<5$ & $<6$ & $<6$ & $<5$ & $<7$ & $<4$ & $<5$ & $<5$ & $<6$ & 6 & $<6$ & 157 & 9 & 41 & $<6$ & 1065 & 111 & 56 & 17 \\
\hline 260607-01 & $<3$ & 97 & 24 & 52 & $<3$ & 15 & $<5$ & $<6$ & $<6$ & $<5$ & $<7$ & $<4$ & $<5$ & $<5$ & $<6$ & 11 & $<6$ & 130 & 68 & 65 & $<6$ & 215 & 422 & 44 & 13 \\
\hline 090607-02 & 8 & 395 & 17 & 15 & $<3$ & 128 & $<5$ & $<6$ & $<6$ & $<5$ & $<7$ & $<4$ & $<5$ & $<5$ & $<6$ & $<6$ & $<6$ & 100 & 22 & 112 & $<6$ & 820 & 19 & 67 & 21 \\
\hline $090607-03$ & $<3$ & 65 & 15 & 10 & $<3$ & 62 & $<5$ & $<6$ & $<6$ & $<5$ & $<7$ & $<4$ & $<5$ & 7 & $<6$ & $<6$ & $<6$ & 80 & 126 & 129 & $<6$ & 1348 & $<5$ & 92 & 21 \\
\hline 130607-12 & 5 & 173 & 15 & 12 & $<3$ & 142 & $<5$ & $<6$ & $<6$ & $<5$ & $<7$ & $<4$ & $<5$ & $<5$ & $<6$ & $<6$ & $<6$ & 86 & 5 & 48 & $<6$ & 202 & 31 & 41 & 15 \\
\hline
\end{tabular}

Table 3

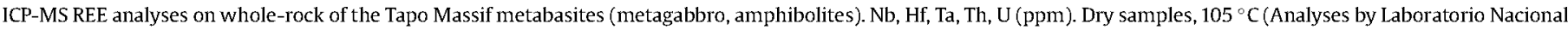
de Energia e Geologia, Porto, Portugal).

\begin{tabular}{|c|c|c|c|c|c|c|c|c|c|c|c|c|c|c|c|c|c|c|c|}
\hline Sample & $\mathrm{La}$ & $\mathrm{Ce}$ & $\operatorname{Pr}$ & $\mathrm{Nd}$ & $\mathrm{Sm}$ & $\mathrm{Eu}$ & $\mathrm{Gd}$ & $\mathrm{Tb}$ & Dy & $\mathrm{Ho}$ & $\mathrm{Er}$ & $\mathrm{Tm}$ & $\mathrm{Yb}$ & Lu & $\mathrm{Nb}$ & Hf & $\mathrm{Ta}$ & Th & $\mathrm{U}$ \\
\hline Lim Quant & 3 & 2 & 0.3 & 0.9 & 0.2 & 0.04 & 0.2 & 0.04 & 0.2 & 0.04 & 0.1 & 0.02 & 0.1 & 0.02 & 0.7 & 2.3 & 0.1 & 0.2 & 1.3 \\
\hline 090606-02 & $<3$ & 2 & 0.3 & 2.1 & 1.2 & 0.74 & 1.8 & 0.39 & 2.8 & 0.65 & 1.9 & 0.27 & 1.8 & 0.28 & $<0.7$ & $<2.3$ & $<0.1$ & $<0.2$ & $<1.3$ \\
\hline 090606-03 & 3 & 9 & 1.7 & 9.4 & 3.5 & 1.81 & 5 & 1 & 7.1 & 1.45 & 4.2 & 0.62 & 4.1 & 0.61 & 1.2 & $<2.3$ & 0.1 & $<0.2$ & $<1.3$ \\
\hline 260607-01 & $<3$ & 7 & 1.2 & 6.3 & 2.3 & 0.87 & 3.2 & 0.60 & 4.2 & 0.91 & 2.7 & 0.38 & 2.5 & 0.39 & 2.1 & $<2.3$ & 0.1 & 0.2 & $<1.3$ \\
\hline 090607-02 & $<3$ & 2 & 1.6 & 2.1 & 1.1 & 1.20 & 1.8 & 0.37 & 2.7 & 0.63 & 1.7 & 0.27 & 1.7 & 0.29 & $<0.7$ & $<2.3$ & $<0.1$ & $<0.2$ & $<1.3$ \\
\hline $090607-03$ & $<3$ & $<2$ & $<0.3$ & 1.6 & 0.9 & 0.61 & 18 & 0.36 & 2.7 & 0.63 & 1.8 & 0.28 & 1.8 & 0.29 & $<0.7$ & $<2.3$ & $<0.1$ & $<0.2$ & $<1.3$ \\
\hline $130607-12$ & $<3$ & 2 & 0.3 & 2.2 & 1 & 0.56 & 1.6 & 0.32 & 2.5 & 0.55 & 1.6 & 0.24 & 1.7 & 0.27 & $<0.7$ & $<2.3$ & $<0.1$ & $<0.2$ & $<1.3$ \\
\hline
\end{tabular}




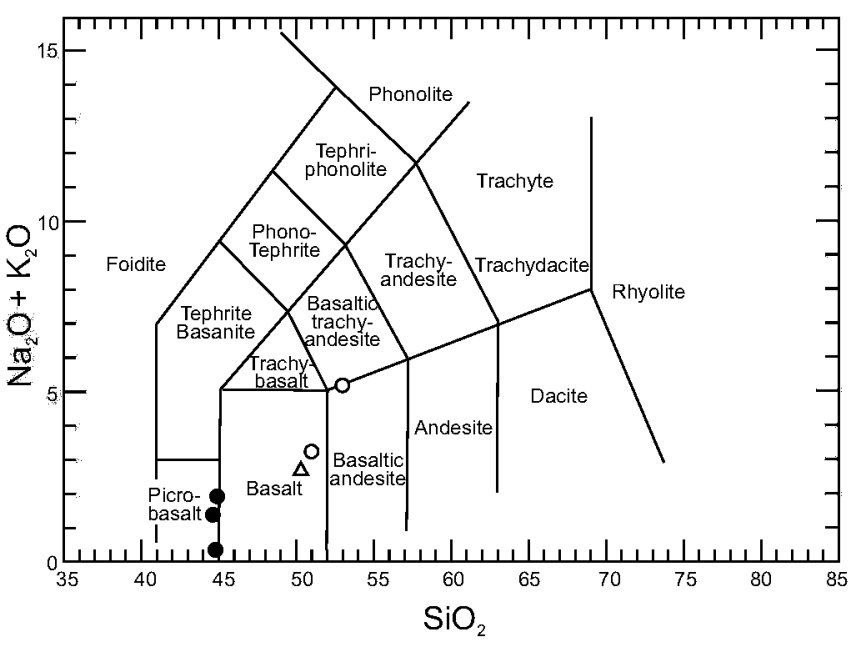

Fig. 5. $\mathrm{Na}_{2} \mathrm{O}+\mathrm{K}_{2} \mathrm{O}$ versus $\mathrm{Si}_{2} \mathrm{O}$ diagram with metabasite projections, with additional fields of igneous rock types (TAS diagram, Le Maitre et al., 1989).

are also found as minor minerals. The chromite grains show minute silicate inclusions and a delicate zoning.

Samples TP140607-30 and TP150607-33 are chromite samples from the Tomasa and San Felipe mines, respectively. They both comprise massive chromite with brecciated cumulatic texture, and with subordinate amounts of serpentine or chlorite. Minor components in TP140607-30 are magnetite and very scarce tiny chalcopyrite inclusions in chromite. No magnetite has been observed in TP150607-33; instead, minute sulphide inclusions in chromite can be frequently observed (pyrite, pyrrhotite and possible millerite).

Analysis from the gabbro, were performed on separated plagioclase and amphibole concentrates and on whole-rock. The amphibole concentrate was dated by $\mathrm{K}-\mathrm{Ar}$ technique. The samples were broken into small pieces and were further reduced in size using a ceramic jaw-crusher and finally into powder (whole-rock) with Molybdenun ball mill. A mineral separate was obtained by using Frantz magnetic separation and heavy liquids, and then handpicked under a binocular microscope.

$\mathrm{Sm}-\mathrm{Nd}$ and $\mathrm{K}-\mathrm{Ar}$ isotopic analyses were carried out at the Geochronological Research Center of the University of São Paulo following the methods detailed in Sato et al. (1995) and Amaral et al. (1967).

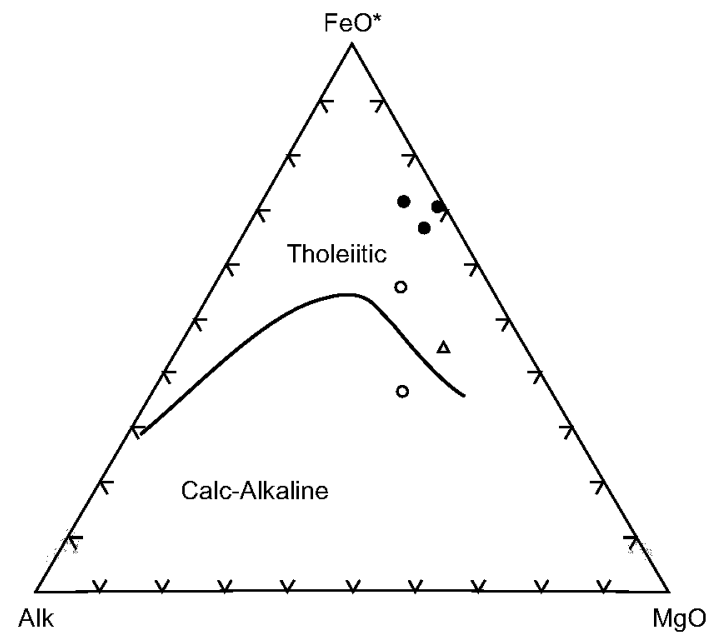

Fig. 6. Alk-FeO*-Mgo diagram (Irvine and Baragar, 1971) with metabasite's analytical points.

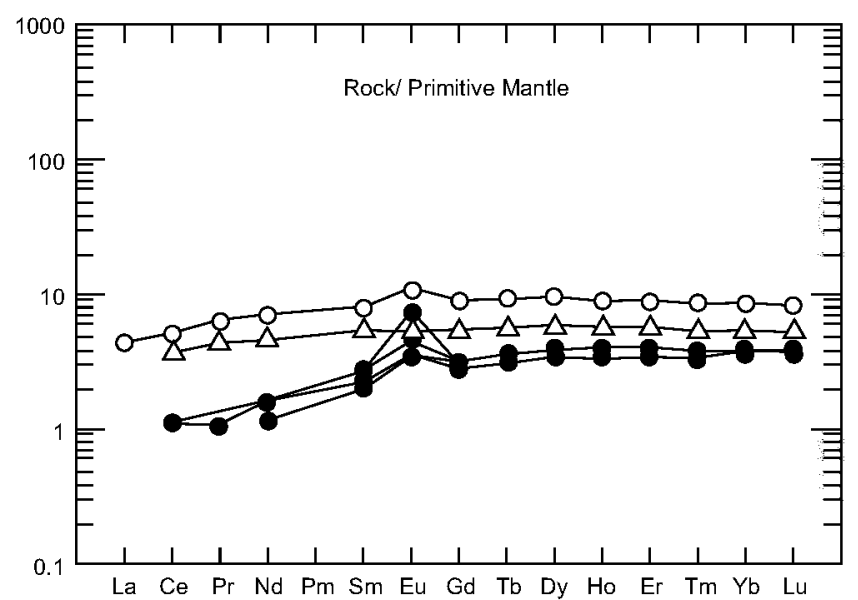

Fig. 7. Rare earth elements (REE) chondrite-normalized spidergram (Palme and O'Neill, 2004) with metabasite projections.

To $\mathrm{Sm}-\mathrm{Nd}$ analysis approximately $0.10-0.15 \mathrm{~g}$ of powdered sample was dissolved for $5-10$ days with a ${ }^{149} \mathrm{Sm}-{ }^{150} \mathrm{Nd}$ mixed spike solution and a combination of hot $\left(60^{\circ} \mathrm{C}\right) \mathrm{HF}$ and $\mathrm{HNO}_{3}$ acids within a Teflon vessel. No visible solid residues were observed after dissolution. Rare earth elements (REE) including Sm and Nd were then extracted using cation exchange columns $\mathrm{HCl}$ elution and $\mathrm{AG}$ $50 \mathrm{~W}-\mathrm{X} 8$ resin $(200-400 \#)$. Sm and $\mathrm{Nd}$ were then separated also using $\mathrm{HCl}$ elution but with hydrogen di-ethylhexyl phosphate (HDEHP) supported by Teflon powder. After loading as a phosphate salt on twin Ta side filaments with a rhenium centre ionizing filament, the $\mathrm{Sm}$ and $\mathrm{Nd}$ concentrations and isotopic composition were measured on a Finnigan - MAT 262 automated mass spectrometer $\mathrm{Nd}$ ratios were normalized to a ${ }^{146} \mathrm{Nd} /{ }^{144} \mathrm{Nd}=0.72190$. The averages of ${ }^{143} \mathrm{Nd} /{ }^{144} \mathrm{Nd}$ for La Jolla and BCR-1 standards were $0.511847 \pm 0.00005(2 \sigma)$ and $0.512662 \pm 0.00005(2 \sigma)$ respectively. The isotopic data were regressed using the ISOPLOT program of Ludwig (2003). Ages were calculated using the decay constants established in Steiger and Jager (1977); for ${ }^{147} \mathrm{Sm}$ was $6.54 \times 10^{-12} \mathrm{yr}^{-1}$.

The $\mathrm{K}-\mathrm{Ar}$ age determination was made using techniques described by Amaral et al. (1967) with some modifications. K analyses were made by flame photometry with a Micronal B-262

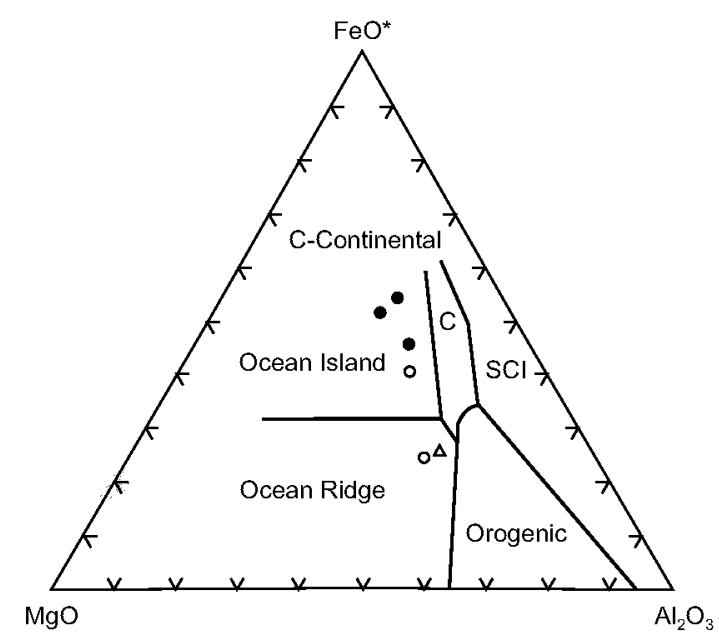

Fig. 8. $\mathrm{MgO}-\mathrm{FeO}^{*}-\mathrm{Al}_{2} \mathrm{O}_{3}$ ternary diagram (Pearce et al., 1977) with metabasite projections related to crustal environment fields. 
Table 4

Sm-Nd analyses for samples from the Tapo Massif.

\begin{tabular}{|c|c|c|c|c|c|c|c|c|}
\hline Field Number & Material/Rock & Sm (ppm) & Nd (ppm) & ${ }^{147} \mathrm{Sm} /{ }^{144} \mathrm{Nd}$ & Error & ${ }^{143} \mathrm{Nd} /{ }^{144} \mathrm{Nd}$ & Error & $\mathrm{E}_{\mathrm{Nd}}(670 \mathrm{Ma})$ \\
\hline $090606-003$ & Whole Rock/Gabbro & 1.646 & 5.400 & 0.1843 & 0.0011 & 0.513010 & 0.000012 & 8.4 \\
\hline TP150607,33 & Chromite/Chromitite & 0.017 & 0.060 & 0.1735 & 0.0010 & 0.512942 & 0.000107 & 8.0 \\
\hline $260607 \mathrm{C}$ & Chromite/Chromitite & 0.452 & 1.916 & 0.1425 & 0.0008 & 0.512795 & 0.000015 & 8.0 \\
\hline TP140607,30 & Chromite/Chromitite & 0.061 & 0.173 & 0.2124 & 0.0013 & 0.513120 & 0.000014 & 8.0 \\
\hline
\end{tabular}

machine, using a lithium internal standard. The Ar extraction was made in a high vacuum system with pressure usually less than $10^{-7} \mathrm{~mm} / \mathrm{Hg}$. Isotopic analysis of the purified argon was made in MS-1 Nuclide mass spectrometer - fully modified. All ages have been calculated with the decay constants recommended by Steiger and Jager (1977) and are given with standard error ( $1 \sigma)$ estimates. The constants used in the calculations are:

$$
\begin{aligned}
& \lambda \beta=4.962 \times 10^{-10} \mathrm{anos}^{-1} \\
& \lambda K=0.581 \times 10^{-10} \mathrm{ano}^{-1} \\
& \left({ }^{40} \mathrm{Ar} /{ }^{36} \mathrm{Ar}\right) \mathrm{atm}=295.5 \\
& { }^{40} \mathrm{~K}=0.01167 \% K_{\text {total }}
\end{aligned}
$$

\section{Results and discussion}

The analytical data of $\mathrm{Sm}-\mathrm{Nd}$ isotopic analyses are shown in Table 4. Analyses of chromites yield Sm and Nd concentrations that range between approximately $0.017-0.452 \mathrm{ppm}$ and $0.06-1.916 \mathrm{ppm}$ respectively. The calculated ${ }^{147} \mathrm{Sm} /{ }^{144} \mathrm{Nd}$ and ${ }^{143} \mathrm{Nd} /{ }^{144} \mathrm{Nd}$ ratios range between $0.1425-0.2124$ and $0.512795-0.513120$, respectively.

Analyses of the chromite host rock were also performed using whole-rock, sample. The two groups overlap in ${ }^{147} \mathrm{Sm} /{ }^{144} \mathrm{Nd}$ and ${ }^{143} \mathrm{Nd} /{ }^{144} \mathrm{Nd}$ ratios, and together both define a line on $\mathrm{Sm}-\mathrm{Nd}$ isochron diagram, with a slope that corresponds an age of $718 \pm 47$ Ma with an initial ${ }^{143} \mathrm{Nd} /{ }^{144} \mathrm{Nd}$ of $0.51213 \pm 0.00005$ and MSWD value of 3.0 (Fig. 9). The defined line can be

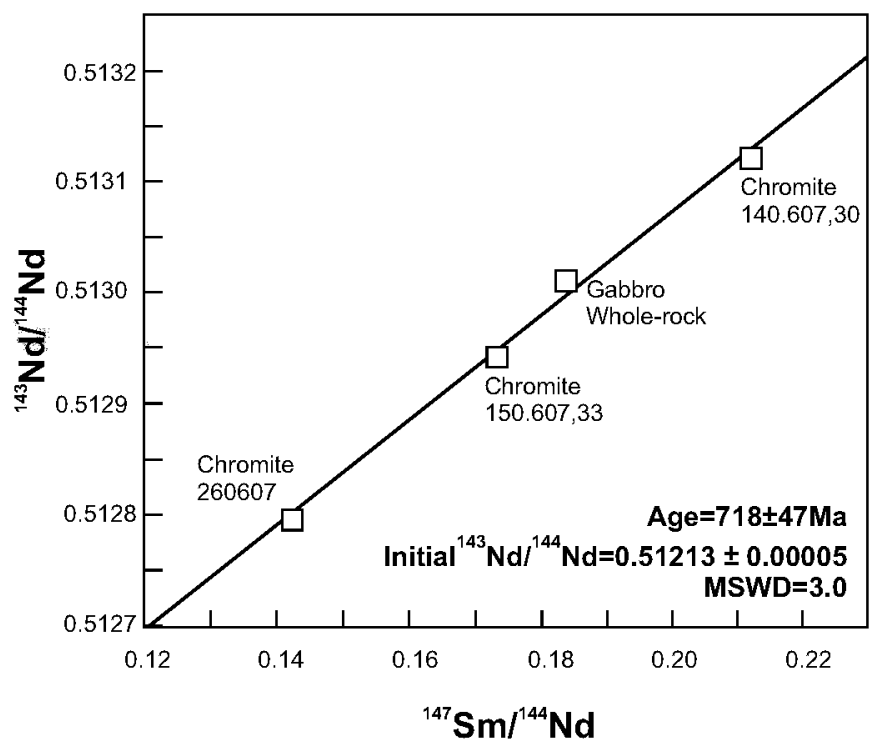

Fig. 9. Sm-Nd isochron for Tapo Ultramafic Massif, including chromites and the host gabbro (analyses on whole-rock). interpreted in two different ways: it can be considered an isochron or it can be considered a mixing line between two end members. In the first case the value of 718 Ma determines the age of the chromites and associated gabbro. In the second case the age has no geological meaning, but simply reflects the $\mathrm{Sm} / \mathrm{Nd}$ ratios and the $\mathrm{Nd}$ isotopic compositions of the two end members (gabbro and chromite).

As the whole-rock samples from gabbro, within the Sm-Nd isochron diagram, is located in between the chromite analytical points and, in consequence, do not clearly define two distinct end members, and all the points (minerals and whole-rock) are in the same alignment, we have chosen to interpret the age of $718 \pm 47$ Ma as the time of the chromite crystallization and the coeval gabbro forming processes.

Table 4 shows that, for the chromite and gabbro whole-rock samples, the $\varepsilon_{\mathrm{Nd}}$ values, calculated for $718 \mathrm{Ma}$, are in close agreement and show a cluster of values at $+\mathbf{8 . 0}$ for the chromites and +8.4 for the gabbro. Such a positive $\varepsilon_{\mathrm{Nd}}$ values suggest that $\mathrm{Nd}$ was derived from the depleted mantle and both, chromite and host gabbro, were formed at same time from the same magma source, which indicate that the chromitite pods have a magmatic origin.

Results of $\mathrm{K}-\mathrm{Ar}$ radiometric determination are shown in Table 5. $\mathrm{K}-\mathrm{Ar}$ analysis performed on amphibole sample from metamorphosed gabbro of Tapo Complex (sample 090606-003) yields an age of $448 \pm 26 \mathrm{Ma}$. This result can be interpreted as the cooling age, indicating that temperature dropped below $500{ }^{\circ} \mathrm{C}$ at the Ordovician, just after the metamorphic peak of the last overprint event that reached the amphibolite facies.

Chew et al. (2007) investigated Eastern Cordillera of Peru by $\mathrm{U}-\mathrm{Pb}$ dating of detrital zircon from Palaeozoic metasedimentary sequences and zircon overgrowths in high-grade leucosomes of paragneisses from the Marañon Complex, as well as zircon from deformed and undeformed granitic rocks. The authors characterized the presence of two important peaks for detrital zircon ages, the first one between 1.3 and $0.9 \mathrm{Ga}$ and the younger between 0.65 and $0.45 \mathrm{Ga}$. These results were interpreted as indicative of the presence of Greenville and Famatinian - Pampean orogenies respectively, as the main detritus sources to the Palaeozoic sequences in the Eastern Cordillera. The 650-530 Ma and 630-610 Ma time periods are also characterized by Cardona et al. (2006) and Dalmayrac et al. (1980) respectively, for detrital zircon grains from the metasedimentary rocks of Marañon Complex and granulitic gneisses in Central Peru.

The zircon overgrowths from foliated leucosome associated with garnet bearing paragneisses from Marañon Complex, were dated by Chew et al. (2007), using $\mathrm{U}-\mathrm{Pb}$ ion-microprobe technique, with an age of $478 \pm 4 \mathrm{Ma}$, that was interpreted as the age of amphibolite facies metamorphism. Within the same metamorphic Complex, Cardona et al. (2006) report an age of $484 \pm 12$ Ma for metamorphic overgrowths in zircon crystals. Additional zircon $\mathrm{U}-\mathrm{Pb}$ ages between 474 and $442 \mathrm{Ma}$ were obtained for a magmatic belt of Central Peru (Chew et al., 2007). Our K-Ar age determination of $448 \pm 26$ Ma obtained on amphibole from gabbro of the Tapo Complex could be related to the cooling of the medium to highgrade metamorphic episode dated back at $484-474$ Ma by Chew et al. (2007) in the Eastern Cordillera or represent the cooling at 
Table 5

$\mathrm{K}$-Ar analytical data for amphibole from metagabbro of the Tapo Massif.

\begin{tabular}{|c|c|c|c|c|c|c|c|c|}
\hline Field Number & Material & Rock Type & $\%$ de $\mathrm{K}$ & Error K\% & $A \mathbf{r}^{40}$ Rad cc STP $/ g\left({ }^{*} 10^{-6}\right)$ & $\operatorname{Ar}^{40} \operatorname{Atm}(\%)$ & Age (Ma) & Error Max (Ma) \\
\hline $090606-003$ & Anphibole & Gabbro & 0.9248 & 0.079 & 1.56 & 52.59 & 448.0 & 26.0 \\
\hline
\end{tabular}

$500{ }^{\circ} \mathrm{C}$, very close to metamorphic peak, of another younger orogenic event.

Based on the regional geochronological pattern established for the Eastern Cordillera and on our geochemical results, the Sm-Nd isochronic age of $718 \pm 47$ Ma defined for the gabbro and associated chromite of the Tapo Complex could be interpreted as the age of production of oceanic lithosphere, near the NW margin of Amazonia. This interpretation appears as the only reasonable to explain the geochemical character of the Tapo protoliths as oceanic crust (Figs. 5-8), and the allochtonous character of the massif as well. It implies local rifting related to some regional extensional event and subsequent closure of the ocean basin, resulting finally in the incorporation of the newly generated crust onto the continental margin. In this case, the age of ca. 720 Ma can be considered as the time of the oceanic crust formation. The mechanism and the age of the sequence of events leading to the emplacement of the ultramafic rocks over the NW Amazonia continental margin can not be established with absolute certainty with the information available. However, recent results of on-going research suggest a subduction event to explain the high pressure metamorphism found on the Tapo rocks ( $\sim 12.5 \pm 1 \mathrm{~kb}, 535 \pm 20^{\circ} \mathrm{C}$, Willner et al., 2010$)$, likely related to a continental collision following the closure of the ocean basin. The age of this metamorphic event is roughly constrained by the cooling below $500{ }^{\circ} \mathrm{C}$ of the amphibole determined by $\mathrm{K}-\mathrm{Ar}$ analysis, as mentioned, at $\sim 450 \mathrm{Ma}$ (Ordovician). However, the emplacement of the Tapo massif in its present position must be certainly younger, as it is thrust on the non-metamorphic Carboniferous sediments of the Ambo Group. This episode may be related to pre-Andean exhumation, since the basal thrust plane is folded by Andean deformation.

These data are in agreement with current ideas about the geotectonic evolution of the region. The pre-Andean history of the Eastern Cordillera of central Peru and neighbouring Amazonia is still poorly constrained, particularly in Precambrian times, but there are some data which allow to draw a general framework, in agreement with current knowledge (Ramos, 2008, 2009, 2010). The region, as NW margin of Amazonia, was part of the Proterozoic supercontinent Rodinia, whose breakup started in late Proterozoic times with rifting along the Laurentia - East Gondwana suture (Dalziel, 1997; Ramos and Alemán, 2000), and later along the E Laurentia margin facing West Gondwana. A $774 \mathrm{Ma}$ A-type magmatism in the Grenville basement of Laurentia (now W Sierras Pampeanas, Argentina) has been reported as precursor of the protracted north-migrating rifting along this margin until 572-564 Ma, leading to the birth of the Iapetus Ocean (Baldo et al., 2006; Casquet et al., 2009). The ca. 720 Ma obtained for the crystallization of the ultramafic and mafic protoliths of the Tapo massif can be understood in the frame of a subordinate rift in the W-Gondwana margin. Similarly, the age of ca. $450 \mathrm{Ma}$ found for the waning stages of metabasite metamorphism fits in the middle Ordovician collision of Laurentia with the proto-andean margin of Gondwana (Dalziel, 1997), or in the frame of a protracted northwards evolution of the FamatinianTaconic orogen (Chew et al., 2007) or Terra Australis Orogen (Cawood, 2005). And, more importantly, the data presented, as a whole, are consistent with the ordovician collision of a basement block, the Paracas parautochthonous terrane (Ramos, 2008, 2009, 2010), against the Gondwana margin in the Central Andes, the suture being represented by the dismembered ophiolites found in the Eastern Cordillera $\left(9^{\circ} 30^{\prime}-11^{\circ} 30^{\prime}\right.$, Castroviejo et al., 2010a,b) among which the Tapo massif is one of the most conspicuous.

The closure of oceanic basins that resulted from consumption of Neoproterozoic oceanic crust related to the growth of West Gondwana, between 660 and 600 Ma can be also observed in other regions of South America, like the Goias Magmatic Arc in Brazil, that have been accreted to the western margin of São Francisco Craton with an important magmatic activity between ca. 630 and $670 \mathrm{Ma}$ (Fuck et al., 2006) and in the Araçuaí (Eastern Brazil) belt, located between the São Francisco and Congo cratons. That orogen include metamorphosed volcanic-exhalative sediments associated with ocean-floor basalts (amphibolites). The magmatic protoliths of these amphibolites crystallized at about $816 \pm 72 \mathrm{Ma}$ and the regional metamorphism reached the amphibolite facies at about 630 Ma (Pedrosa-Soares et al., 1998).

\section{Conclusions}

The Tapo ultramafic-mafic body consists mainly of strongly serpentinised peridotites, with subordinate metagabbros and amphibolites; metasomatic talc-carbonate and silicic occurrences (listvenites and birbirites, respectively) are also found occasionally. Small podiform chromitite bodies and chromite disseminations, and scarcer rodingite outcrops are found as well. Smaller but roughly similar bodies (Acobamba) occur further north of the main ultramafic body (Tapo), and these conclusions apply also for them.

Detailed geological mapping and structural geology of these bodies refutes earlier interpretations as Precambrian autochthonous ultramafic intrusives (diapirs, dykes or sills), and support their characterisation as parts of a dismembered ophiolite (Castroviejo et al., 2010a,b). Actually, the Tapo massif overlies palaeozoic formations. In all the cases (Tapo and Acobamba) the contacts with the host rocks are always of a tectonic origin (thrusts or faults), and thermal metamorphism is never observed. The inner deformation of the ultramafic bodies can not be explained by Andean tectonism, although there is a clear Andean overprint. Finally, even if the Tapo massif is lying on continental crust, its chemistry suggests a slice of oceanic lithosphere. Careful sampling identified some relatively fresh samples of metagabro and amphibolite, whose chemistry corresponds to basalts to picrobasalts of tholeiitic character and oceanic affinity (MORB or island arc). It can be concluded that these bodies are not in situ intrusive bodies, but dismembered slices of oceanic crust, metamorphosed and overthrust on upper Palaeozoic continental formations (Ambo Group, in the case of the Tapo massif) or older metapelites (Huácar Group, Marañón Complex, in the case of the Acobamba bodies).

Our new Sm-Nd data indicate that the Tapo Mafic-Ultramafic magmas crystallized at about 720 Ma. In addition it is suggested that both gabbro and chromite are contemporaneous and they were derived from the same mantelic source. The K-Ar geochronology shows that the Tapo Complex was affected by an Ordovician metamorphic episode, which reached the amphibolite facies; cooling below $500{ }^{\circ} \mathrm{C}$ occurred at ca. $450 \mathrm{Ma}$ (upper Ordovician).

Further details need to be worked out for a comprehensive interpretation. This should also include work in progress on the northernmost ultramafic bodies (Huánuco Department, Rodrigues et al., 2010b), but some fundamental facts related to the evolution of the central Peruvian Eastern Cordillera can already be established: 
- as a consequence of Precambrian rifting probably related to the early stages of Rodinian breakup, ca. 720 Ma, oceanic lithosphere was generated near the NW Amazonian craton, preandean margin;

- some slices of this newly formed crust, including podiform chromitite bodies -, were subducted and involved in the Famatinian or Terra Australis orogen and subject to high pressure metamorphism in middle ordovician times (upto $450 \mathrm{Ma}$ ), probably as part of a basement block, the Paracas terrane, colliding against the western Gondwana margin;

- fragments of this oceanic lithosphere were subsequently overthrust on Upper Palaeozoic sequences of the pre-Andean amazonian margin, and incorporated to the Andean orogen.

\section{Acknowledgements}

Logistical support was provided by Universidad Politécnica de Madrid through the projects AL06PID0010, AL07PID027 \& AL08PID25, as well as by INGEMMET and by the company REPSA, Peru, and financial support to analytical costs by CNPq, Brazilian National Research Council. We thank the technical staff of the Geochronological Research Center of University of São Paulo for their help during the isotopic analysis period, in special Mr. Vasco Loios and Liliane Petronilho by samples preparation work. Support by LNGE, Porto and by Dr. F. Bellido, IGME_Madrid, Spain, for additional geochemical analyses and for their discussion; by Dr. J Macharé, Director Ejecutivo, Dr. H. Chirif, Director Rec. Minerales, D. Romero, and J. Quispe, INGEMMET, and by Dr. R. Carrascal and R. Uribe, UNI, Lima, Peru, is gratefully acknowledged. The authors greatly appreciate the insightful reviews made by the anonymous reviewers and the editor's suggestion.

\section{References}

Amaral, G., Bushee, I., Cordani, U.G., Kawashita, K., Reynolds, J.H., 1967. Potassium-argon age of alkaline rocks from Southern Brazil. Geochimica et Cosmochimica Acta 31, 117-142.

Baldo, E., Casquet, C., Pankhurst, R.J., Galindo, C., Rapela, C.W., Fanning, C.M., Dahlquist, J., Murra, J., 2006. Neoproterozoic A-type magmatism in the Western Sierras pampeanas (Argentina): evidence for Rodinia break-up along a protolapetus rift? Terra Nova 18 (6), 388-394.

Cardona, A., Cordani, U.G., Ruiz, J., Valencia, V., Nutman, A.P., Sanchez, A., 2006. U/Pb Detrital Zircon Geochronology and Nd Isotopes from Paleozoic Metasedimentary Rocks of Marañon Complex: Insights on the Proto-Andean Tectonic Evolution of the Eastern Peruvian Andes. In: Fifth South American Symposium on Isotope Geology, short papers, vol. 208-211.

Casquet, C., Rapela, C.W., Pankhurst, R.J., Baldo, E., Galindo, C., Saavedra, J., 2009 Paleoproterozoic terranes in southern South América: accretion to Amazônia involvement in rodinia formation and further W. Gondwana accretion. In: Proc Geol. Soc. London Fermor Meeting, Rodinia: Supercontinents, Superplumes and Scotland. Edinburgh.

Castroviejo, R., Rodrigues, J.F., Acosta, J., Pereira, E., Romero, D., Quispe, J., Espí, J.A. 2009a. Geología de las ultramafitas pre-andinas de Tapo y Acobamba, Tarma, Cordillera Oriental del Peru, vol. 46. Geogaceta, SGE, Madrid, pp. 7-10.

Castroviejo, R., Pereira, E., Rodrigues, J.F., Acosta, J., 2009b. Pre-andean serpentinite-chromite orebodies in the Eastern Cordillera of Central Peru, Tarma province. In: Proc. 10th Biennial SGA Meeting. Townsville, Australia, pp. 927-929.

Castroviejo, R., Rodrigues, J.F., Carrascal, R., Chirif, H., Acosta, J., Uribe, R., $2009 \mathrm{c}$ Mineralogía del Macizo Ultramáfico de Tapo (Cordillera Oriental Angina, Peru), vol. 11. Rev. Soc. Española de Mineralogía, Macla, pp. 55-56.

Castroviejo, R., Rodrigues, J.F., Tassinari, C.C.G., Pereira, E., Acosta, J., 2010a. Ophiolites in the Eastern Cordillera of the central Peruvian Andes. In: IMA2010 Congr. (20th General Meet. Internat. Mineralogical Association). Acta Mineral. Petrogr. Abstr. Ser. Szeged, Budapest, p. 587. (CD_ROM, Proc. Session GP83_Ophiolites: from spreading to emplacement, Code GP83_P04_N2). Budapest, Hungary, 21-27 August 2010.
Castroviejo, R., Macharé, J., Castro, P., Pereira, E., Rodrigues, J.F., Tassinari C.G., Willner A., Acosta J., 2010b. Significado de las ofiolitas neoproterozoicas en la Cordillera Oriental del Perú. Simposio S3_Bloques Litosféricos de la Cadena Andina. XV Congr Peruano de Geología. Cusco.

Castroviejo, R., Carrascal, R., Chirif, H., Rodrigues, J.F., Acosta, J., Bernhardt, H.J., 2010c. Metalogenia asociada a los segmentos ofiolíticos de la Cordillera Oriental del Perú Central. Simposio S3_Bloques Litosféricos de la Cadena Andina. In: XV Congr. Peruano de Geología. Cusco.

Cawood, P.A., 2005. Terra Australis orogen: rodinia breakup and development of the Pacific and lapetus margins of Gondwand during the Neoproterozoic and Paleozoic. Earth-Sci. Rev. 69, 249-279.

Chew, D.M., Schaltegger, U., Kosler, J., Whitehouse, M.J., Gutjahr, M. Spikings, R.A., Miskovic, A., 2007. U-Pb geochronology evidence for the evolution of the Gondwana margin of the north-central Andes. GSA Bull. 119, $697-711$.

Dalmayrac, B., Laubacher, G., Marocco, R., 1980. Geologie des Andes Peruviénnes. Caractéres Generaux de l'Evolucion Geologique des Andes Péruviennes: Paris, Travaux et Document de Loffice de La Recherchè Scientifique et Technique Outre-mer, vol. 122 , p. 501.

Dalziel, I.W.D., 1997. Neoproterozoic-Paleozoic geography and tetctonics: review, hypothesis, environmental speculation. GSA Bull. 109 (1), 16-42.

Fanlo, I., Gervilla, F., Castroviejo, R., Rodrigues, J.F., Pereira, E., Acosta, J., Uribe, R., 2009. Metamorphism of chromitites in the Tapo ultramafic massif, Eastern Cordillera, Peru. In: Proc. 10th Biennial SGA Meeting. Townsville, Australia, pp. 161-163.

Fuck, R.A., Dantas, E.L., Pimentel, M.M., Laux, J.H., Junges, S.L., Oliveira, C.G., Sordi, D.A. Chiarini, M.F.N., 2006. The Santa Terezinha Sequence, Goiás Magmatic Arc, Central Brazil: Constrains from U-Pb and Sm-Nd Data (V SSAGI, Extended Abstract CD-ROM, Montevideo Uruguay).

Irvine, T.N., Baragar, W.R.A., 1971. A guide to the chemical classification of the common volcanic rocks. Can. J. Earth Sci. 8, 523-548.

Le Maitre, R.W., Bateman, P., Dudek, A., Keller, J., Lameyre, P., Le Bas, M.J., Sabine, P.A., Schmid, R., Sorensen, H., Streckeisen, A., Woolley, A.R., Zanettin, B., 1989. A Classification of Igneous Rocks and Glossary of Terms. Blackwell, Oxford.

Ludwig, K.R., 2003. User's Manual for Isoplot/Ex, Version 3.0, a Geochronological Toolkit Fpr Microsoft Excell. Berkely Geochronology Center Special Publication. 4

Megard, F., Caldas, J., Paredes, V.J., Cruz, N., 1996. Geología de los cuadrángulos de Tarma, La Oroya y Yauyos (Menoria). Bol. N $^{\circ} 69$ serie A. INGEMMET, Lima, p. 227.

Palme, H., O'Neill, H.C., 2004. Cosmochemical Estimates of Mantle Composition. 1-38 (Holland, H.D., Turekian, K.K. (Eds.)). In: Carlson, R.W. (Ed.), The Mantle and Core. Treatise on Geochemistry, vol. 2. Elsevier-Pergamon, Oxford.

Pearce, T.H., Gorman, B.E., Birkett, T.C., 1977. The relationship between major element chemistry and tectonic environment of basic and intermediate volcanic rock. Earth Planet. Sci. Lett. 36, 121-132.

Pedrosa-Soares, A.C., Vidal, P., Leonardos, O.H., Brito Neves, B.B., 1998. Neoproterozoic oceanic remnants in eastern Brazil: further evidence and orogen refutation of an exclusive ensialic evolution for the Araçuaí-West Congo orogen. Geology 26, 519-522.

Ramos, V.A., 2008. The basement of the Central Andes: the Arequipa and related terranes. Annu. Rev. Earth Planet. Sci. 36, 289-324.

Ramos, V.A., 2009. Anatomy and Global Context of the Andes: Main Geologic Features and the Andean Orogenic Cycle, vol. 204. The Geological Society of America, Memoir, pp. 31-65.

Ramos, V.A., 2010. The Grenville-age basement of the Andes. J. South Am. Earth Sci. $29,77-91$.

Ramos, V.A., Alemán, A., 2000. Tectonic evolution of the Andes. In: Cordani, U.G. Milani, E.J., Thomaz Filho, A., Campos, D.A. (Eds.), Tectonic Evolution of South America, 31st. Internat. Geol. Congr. Río de Janeiro, pp. 635-685.

Rodrigues, J.F., Acosta, J., Castroviejo, R., Quispe, J., Romero, D., Uribe, R., Campián, M., 2010a. Geología y estructura de las ultramafitas de Tapo y Acobamba (Tarma, Perû). Removilización tectónica andina de un segmento ofiolítico preandino. Simposio S3_Bloques Litosféricos de la Cadena Andina. In: XV Congr Peruano de Geología. Cusco.

Rodriques, J.F., Acosta, J., Macharé, J., Pereira, E., Castroviejo, R., 2010b. Evidencias estructurales de aloctonía de los cuerpos ultramáficos y máficos de la Cordillera Oriental del Perú en la Región de Huánuco. Simposio S3_Bloques Litosféricos de la Cadena Andina. In: XV Congr Peruano de Geología. Cusco.

Sato, K., Tassinari, C.C.G., Kawashita, K., Petronilho, L., 1995. o método geocronológico Sm-Nd no IG/USP e suas aplicações. Anais da Academia Brasileira de Ciências 67 (3), 315-336.

Steiger, R.H., Jager, E., 1977. Subcomission on geochronology: convention on the use of decay constants in geo and cosmochronology. Earth Planet. Sci. Lett. 36, $359-362$.

Willner, A., Castroviejo, R., Rodrigues, J.F., Acosta, J., Rivera, M., 2010. High pressure metamorphic conditions in garnet amphibolite from a collisional shear zone related to the Tapo ultramafic body, Eastern Cordillera of Central Peru. Simposio S3_Bloques Litosféricos de la Cadena Andina. In: XV Congr Peruano de Geología. Cusco. 